\title{
DUKUNGAN KELUARGA DALAM PENCEGAHAN \\ KEJADIAN MULTIDRUG RESISTENCE PADA PASIEN TUBERKULOSIS
}

\author{
Beti Kristinawati ${ }^{1 *}$, Siti Rahmawati ${ }^{2)}$ \\ ${ }^{1)}$ Keperawatan Medikal Bedah, Program Studi Keperawatan, Fakultas Ilmu \\ Kesehatan, Universitas Muhammadiyah Surakarta \\ ${ }^{2)}$ Program Profesi Ners, Program Studi Keperawatan, Fakultas Ilmu Kesehatan, \\ Universitas Muhammadiyah Surakarta. \\ e-mail:bk115@ums.ac.id
}

\begin{abstract}
ABSTRAK
Pengobatan Tuberculosis yang tidak tepat dapat menyebabkan terjadinya resistensi obat atau multidrug resistant. Dukungan keluarga dibutuhkan dalam pengobatan dan perawatan pasien Tuberkulosis. Penelitian ini bertujuan untuk mengetahui hubungan dukungan keluarga dengan pencegahan kejadian multidrug resistence pada pasien Tuberculosis. Metode penelitian kuantitatif dengan desain diskriptif korelatif melalui pendekatan cross sectional digunakan dalam penelitian ini. Responden yang dilibatkan adalah seluruh pasien Tuberkulosis di wilayah kerja Puskesmas Sangkrah dan Pajang yang berhasil dalam pengobatan dan tidak mengalami multidrug resistance sebanyak 48 responden. Hasil penelitian didapatkan ada hubungan antara dukungan keluarga dengan pencegahan kejadian multidrug resistence dengan nilai signifikansi $p$ sebesar 0,026 dan dukungan emosional merupakan bentuk dukungan paling tinggi dengan nilai rata-rata sebesar 18,04 .
\end{abstract}

Kata kunci: Dukungan keluarga; Tuberculosis-multidrug resistant

\begin{abstract}
Inadequate Tuberculosis treatment can cause drug resistance or multidrug resistant. Family support is needed in the treatment and care of Tuberculosis patients. This research aims to determine the relationship of family support with the prevention of multidrug resistance in patients Tuberculosis. The quantitative research method with a correlative descriptive design through a cross sectional approach was used in this study. Respondents involved were all tuberculosis patients in the working area of Sangkrah and Pajang Puskesmas who succeeded in the treatment and did not experience multidrug resistance as much as 48 respondents. The results of the study gained a relation between family support and the prevention of multidrug resistance with significance value $p$ of 0.026 and emotional support is the highest form of support with an average value of 18.04 .
\end{abstract}

Keywords: Family suppor;, Tuberculosis-multidrug resistan

Jurnal Kesehatan Holistic/ Volume 4/ Nomor 1/Januari 2020

(ISSN: 2548-1843, EISSN: 2621-8704) 


\section{PENDAHULUAN}

Tuberkulosis merupakan penyakit menular yang diakibatkan oleh Mycobacterium Tuberculosis (Hariadi et al., 2019). Penyakit tuberculosis yang tidak mendapatkan pengobatan dengan baik sampai tuntas akan mengakibatkan terjadinya resistensi obat atau tuberculosis multidrug resistant. Tuberculosis Multidrug Resistant (TB-MDR) merupakan penyakit Tuberkulosis (TB) yang telah mengalami resistensi terhadap isoniazid (INH) dan rifampicin serta satu atau lebih obat anti tuberkulosis (OAT). TB-MDR terjadi karena kegagalan pengobatan, putus pengobatan, atau pengobatan yang tidak benar sehingga terjadinya resistensi primer (WHO, 2015). Sumber penularan tuberculosis terjadi pada pasien TB BTA positif melalui percik renik dahak yang dikeluarkan dan terhirup orang lain (Inayah \& Wahyono, 2019). Penyakit tuberkulosis menduduki peringkat kedua penyebab kematian akibat penyakit infeksi di dunia.

Menurut World Health Organization WHO (2018) 8\% penyumbang kasus
TB di dunia adalah Indonesia, dengan jumlah kasus terbanyak kedua setelah India (Noviarisa, Yani, \& Basir, 2019). Pada tahun 2015 WHO melaporkan MDR-TB meningkat 3\% dan lebih tinggi dari yang diperkirakan yaitu 480 ribu kasus baru dan 100 ribu orang baru memenuhi syarat pengobatan MDRTB dengan TB rifampisin (WHO, 2015). Indonesia menempati urutan ke-4 dunia dengan 32.000 kasus (WHO, 2016). Kementerian Kesehatan RI (2014) melaporkan ada sekitar 6.900 pasien TB-MDR dengan 5.900 kasus baru dan 1.000 orang dari kasus pengobatan ulang (Kemenkes RI, 2014).

Pengobatan tuberkulosis paru yang dilakukan di Indonesia menggunakan strategi DOTS (Directly Observed Treatment Short-course). Fokus utama DOTS adalah penemuan dan penyembuhan pasien dengan prioritas diberikan kepada pasien tuberkulosis tipe menular. Strategi ini akan memutuskan penularan tuberculosis dan menurunkan insidens tuberkulosis di masyarakat (Beauty, 2016). Pengobatan tuberculosis dilakukan melalui 2 
tahapan, yaitu tahap intensif dan lanjutan, pada fase intensif pengobatan dilakukan selama 2 bulan dan dilanjutkan dengan fase lanjutan selama 4-6 bulan. Untuk waktu pengobatan jangka pendek yaitu 6-9 bulan, dan jangka panjang 12-18 bulan (Tristiana et al., 2019). Beban penyakit tuberculosis semakin bertambah seiring meningkatnya penemuan kasus TB MDR (Tuberkulisi Resistant Obat Ganda).

TB Resisten Obat adalah keadaan dimana kuman micobacterium Tuberculosis sudah tidak dapat lagi dibunuh dengan salah satu atau lebih obat anti TB (OAT). TB-MDR merupakan mycobacterium tuberculosis yang resisten terhadap minimal dua obat anti TB lini pertama, yaitu terhadap rifampisin dan INH dengan atau tanpa OAT lainnya. Penanganan TB dengan resisten obat ganda harus teliti, teratur dan patuh apabila ingin sembuh secara total, karena TB yang mengalami resisten obat ganda lebih sulit dikendalikan, hal ini disebabkan penegakan diagnosa yang sulit, tingginya angka kegagalan terapi dan kematian (Janan, 2019).
Hasil studi pendahuluan dilakukan pada tanggal 31 juli di Puskesmas Pajang didapatkan data dengan jumlah kasus pasien tuberkolusis positif di Puskesmas Pajang sebanyak 12 orang dan di Puskesmas Sangkrah didapatkan data dengan jumlah kasus sebanyak 36 orang, jumlah kedua puskesmas 48 kasus tuberkulosis. Penelitian ini sesuai dengan temuan di Magetan yang menunjukkan bahwa kualitas hidup pasien TB ketika menjalani pengobatan bergantung pada kondisi fisik yang dialami, tekanan emosional, koping individu dan keluarga, dukungan sosial yang diperoleh dari keluarga maupun orang sekitar, serta lingkungan yang mendukung pasien TB paru dalam menjalani hidup (Tristiana et al., 2019).

Penelitian Hariadi et al. (2019) di Bengkulu menyatakan bahwa dukungan keluarga mempunyai peran penting terhadap proses pengobatan pasien TB. Dukungan keluarga merupakan unsur yang terpenting dalam individu menyelesaikan masalah. Dukungan keluarga akan menambah rasa 
percaya diri dan memotivasi untuk menghadapi masalah dan meningkatkan kepuasan hidup, keluarga merupakan support sistem utama bagi penderita TB dalam mempertahankan kesehatannya. Asuhan pada individu dengan tuberkulosis diterapkan dengan melibatkan keluarga sebagai pemberi perawatan langsung pada anggota keluarga dengan TB. Penelitian ini bertujuan untuk mengetahui hubungan dukungan keluarga dengan pencegahan kejadian multidrug resistence pada pasien tuberculosis.

\section{METODE}

Penelitian kuantitatif dengan desain diskriptif korelatif yang menggunakan pendekatan cross sectional diterapkan dalam penelitian ini. Populasi target dalam penelitian ini adalah keluarga yang merawat pasien Tuberkulosis dan menjalani pengobatan di Puskesmas Pajang Surakarta periode tahun 2018 serta berhasil menjalani pengobatan TB dan tidak mengalami MDR. Responden yang dijadikan sampel dalam penilitian ini sebanyak 48 orang yang ditentukan dengan teknik total sampling. Sampel yang dipilih memenuhi kriteria yang telah ditetapkan meliputi: telah merawat anggota keluarga yang menderita TB minimal 6 bulan, tinggal dalam satu rumah dan terlibat langsung dalam proses perawatan penderita TB. Data demografi responden ditampilkan pada tabel 1 .

Data dalam penelitian ini dikumpulkan dengan menggunakan instrumen kuesioner yang berisi dukungan keluarga, terdiri dari 12 butir pertanyaan dan kuesioner keberhasilan dalam pengobatan TB yang terdiri dari 15 butir pertanyaan. Instrumen yang digunakan telah diuji validitas dan reliabilitasnya pada 20 anggota keluarga penderita TB yang menjalani pengobatan TB di Puskesmas Pajang pada periode tahun 2017 dan berhasil dalam pengobatannya serta tidak mengalami MDR. Data dasar responden diperoleh dari sumber data di Puskesmas Pajang. Data dalam penelitian dikumpulkan pada bulan Maret 2019 - April 2019 (satu bulan). Teknik pengumpulan data dilakukan dengan cara peneliti melakukan kunjungan ke rumah penderita TB sesuai dengan data 
dasar yang diperoleh dari Puskesmas.

Peneliti menemui keluarga penderita

TB dan menjelaskan tujuan penelitian serta meminta kesediaannya menjadi responden. Peneliti mendampingi responden selama pengisian kuesioner dan memberikan penjelasan ketika ada hal yang tidak dipahami oleh responden.

Data yang terkumpul dianalisis dengan software komputer. Tahap pertama yang dilakukan dalam analisis adalah melakukan penyuntingan data (editing) dengan cara mengecek kelengkapan data yang akan dianalisis. Tahap selanjutnya yaitu dengan membuat kode (coding) pada data yang akan dianalisis. Kode yang dibuat untuk pertanyaan tentang dukungan keluarga yaitu 1 untuk jawaban tidak pernah, 2 untuk jawaban kadang-kadang, 3 untuk jawaban sering dan 4 untuk jawaban selalu. Kode yang dibuat untuk pertanyaan keberhasilan pengobatan TB yaitu 0 untuk jawaban tidak dan 1 untuk jawaban ya. Tahap selanjutnya yaitu memasukkan data ke program komputer. Tahap akhir dalam proses analisa data adalah malakukan tabulasi data (tabulating) yaitu mengelompokkan data dalam tabel yang telah ditentukan oleh peneliti. Analisis univariat digunakan dalam penelitian ini untuk mengolah data karakteristik responden. Sedangkan analisis bivariat Spearman Rank digunakan untuk menguji hubungan antara dukungan keluarga dengan kejadian MDR.

Surat persetujuan etik diperoleh dari Komite Etik Fakultas Kedokteran Universitas Muhammaiyah Surakarta. Penelitian ini bersifat suka rela dan tidak menimbulkan resiko baik di masa sekarang maupun masa yang akan datang. Calon responden yang bersedia berperan serta dalam penelitian diminta menandatangani surat kesediaan berpartisipasi dalam penelitian/informed

concent. Kerahasiaan responden dijaga dengan cara menuliskan inisial sebagai ganti nama responden dengan memberikan kode R1, R2, .. R48. Informasi yang diperoleh selama penelitian dijaga kerahasiaannya dan hanya data tertentu serta mendapat persetujuan dari responden yang dipublikaskan. 


\section{HASIL DAN PEMBAHASAN}

Hasil penelitian ini menjelaskan tentang analisa univariat dan bivariat pada variabel dependen dukungan keluarga dan variabel independen pencegahan kejadian multidrug resistence dengan penjabaran sebagai berikut:

Tabel 1.

Distribusi Frekuensi Karakteristik Responden (n=48)

\begin{tabular}{lcc}
\hline $\begin{array}{c}\text { Karakteristik } \\
\text { responden }\end{array}$ & Frekuensi & Presentase (\%) \\
\hline Jenis Kelamin & & \\
Laki-laki & 37 & 77,1 \\
Perempuan & 11 & 22,9 \\
Umur & & 25,0 \\
21-39 tahun & 12 & 41,7 \\
40-49 tahun & 20 & 33,3 \\
> 60 tahun & 16 & \\
Pendidikan & & 20,8 \\
SD & 10 & 45,8 \\
SMP & 22 & 18,8 \\
SMA & 9 & 14,6 \\
Perguruan Tinggi & 7 & 29,2 \\
Pekerjaan & & 37,5 \\
Tidak bekerja & 14 & 20,8 \\
Buruh & 18 & 12,5 \\
Swasta & 10 & 6 \\
PNS & 6 & \\
\hline
\end{tabular}

Dari hasil distribusi frekuensi karakteristik responden presentase terbesar yaitu responden dengan jenis kelamin laki-laki 77,1\%, responden dengan umur 40-49 tahun $41,7 \%$, responden dengan pendidikan SMP 45,8\%, dan responden yang bekerja sebagai buruh $37,5 \%$.

Karakteristik responden dalam penelitian menunjukkan presentase terbesar penderita TB diderita oleh laki-laki, hal ini sesuai dengan penelitian Sukmawati (2017) yang menyatakan bahwa secara fisiologis volume dan kapasitas paru berbeda

pada laki - laki dan perempuan, perempuan memiliki kapasitas lebih kecil $20-25 \%$ dari pada laki-laki, karena laki - laki memiliki mobilitas yang tinggi daripada perempuan, sehingga kemungkinan untuk terpapar lebih besar, selain itu kebiasaan merokok dan mengkonsumsi alkohol dapat memudahkan laki - laki terinfeksi Tuberkulosis (TB). Menurut Tamamengka \& Kepel (2019) karakteristik responden jenis kelamin laki-laki lebih tinggi karena merokok 
tembakau, minum alkohol dan sering keluar malam/begadang. Hal ini karena alkohol, rokok, dan begadang menurunkan sistem pertahanan tubuh, sehingga lebih mudah terpapar dengan agen penyebab TB Paru.

Responden dalam penelitian menunjukkan umur 40-49 tahun mempunyai presentase terbesar yaitu $41,7 \%$. Pada fase usia pertengahan seseorang akan cenderung lebih aktif dalam berinteraksi sosial sehingga keterpaparan terhadap infeksi TB akan lebih besar. Salah satu faktor yang mempengaruhi kejadian TB paru adalah usia 15-50 tahun. Usia dan kepatuhan pada penderita TB saling berhubungan erat. Karena di usia produktif memiliki tingkat kesadaran yang tinggi akan pengobatan, di usia tersebut mereka harus bekerja untuk memenuhi kebutuhan keluarga (Ismah \& Novita, 2017). Penelitian yang sama juga disampaikan oleh Laily, et al.
(2015) bahwa penderita TB paling banyak ada di usia produktif, yakni 26-45 tahun.

Responden penelitian paling banyak berada di tingkat pendidikan SMP $45,8 \%$. Pendidikan adalah faktor yang mempengaruhi seseorang dalam pencarian pengobatan. Pendidikan seseorang akan berdampak pada pekerjaan yang ia dapatkan, dan sangat berpengaruh terhadap pendapatan (Ismah \& Novita, 2017). Data pekerjaan responden paling banyak adalah sebagai buruh $37,5 \%$. Jenis pekerjaan penderita TB menentukan faktor risiko yang harus dihadapi. Pekerjaan yang berada di lingkungan yang berdebu akan meningkatkan risiko terjadinya gangguan pada saluran pernapasan. Pekerjaan di tempat yang lembab serta dengan pencahayaan dan ventilasi yang kurang baik, meningkatkan risiko terjadinya penularan di tempat kerja (Sari, 2014). 
Tabel 2

Bentuk Dukungan Keluarga $(n=48)$

\begin{tabular}{lcccc}
\hline & \multicolumn{3}{c}{ Bentuk Dukungan } \\
\cline { 2 - 5 } & Penilaian & Instrumental & Emosional & Informasional \\
\hline Rata-rata & 8,97 & 9,06 & 18,04 & 9,18 \\
Std. Deviasi & 1,630668 & 1,73090 & 3,148551 & 1,794227 \\
Median & 9,0 & 9,5 & 19,0 & 10,0 \\
Nilai Max & 12 & 12 & 24 & 12 \\
Nilai Min & 6 & 5 & 11 & 5 \\
\hline
\end{tabular}

Hasil penelitian menunjukkan bentuk dukungan emosional merupakan bentuk dukungan paling tinggi dengan rata-rata sebesar 18,04. Sedangkan bentuk dukungan paling rendah adalah bentuk dukungan penilaian dengan nilai rata-rata sebesar 8,97.

Dukungan keluarga secara emosional pada pasien tuberkulosis dalam penelitian ini menunjukkan dukungan keluarga dapat meningkatkan mekanisme koping individu. Penelitian Niven (2012) menyatakan hal yang sama, bahwa dengan memberikan dukungan emosi dan saran-saran mengenai strategi alternative yang didasarkan pengalaman sebelumnya dan ajakan untuk fokus pada aspek-aspek yang lebih positif akan meningkatkan mekanisme koping seseorang. Dalam penelitian Khasanah

(2017)

dukungan keluarga berhasil berperan dalam mendukung kepatuhan penderita diabetes melitus dalam melakukan aktivitas fisik. Dukungan keluarga merupakan hal utama bagi anggota keluarga lainnya yang sedang sakit. Penelitian ini sesuai dengan pendapat Tirtana (2011) bahwa keluarga merupakan sebuah sumber pertolongan praktis dan konkrit, dalam hal ini penderita TB memerlukan pertolongan dari keluarga. Keluarga berperan sebagai kolektor dan desiminator informasi. Keluarga juga berperan dalam memberikan dukungan emosional, karena keluarga sebagai tempat yang aman dan damai untuk istirahat, pemulihan, dan membantu mengontrol emosi. Dukungan keluarga tidak hanya efektif dalam mengontrol emosional saja, tetapi 
juga berperan sebagai akomodator dukungan instrumental pasien dengan masalah kronis. Penelitian (Kurniawan et al. (2015) menyatakan bahwa kepatuhan dalam pengobatan akan meningkat ketika pasien mendapatkan bantuan dari keluarga sedangkan pada pasien yang tidak memiliki keluarga atau nonsupportive/ nonavailable/ conflicted family berpengaruh terhadap terminasi yakni hasil yang tidak memuaskan.

Tabel 3

Hasil Uji Normalitas Data $(\mathrm{n}=48)$

\begin{tabular}{ccc}
\hline Variabel & p-value & Keputusan \\
\hline Dukungan Keluarga & 0,120 & Normal \\
Pencegahan Multidrug & 0,078 & Normal \\
Resistance & & \\
\hline
\end{tabular}

Hasil Uji Normalitas Data nilai p-value sebesar 0,078 menunjukkan bahwa nilai $p$-value $\quad(0,078<0,05)$ karena $p$-value lebih lebih dari 0,05 maka data dari 0,05 maka data pada variable berdistribusi normal, pada variable keberhasilan minum obat keberhasilan minum obat diketahui berdistribusi normal.

Tabel 4

Tabel Korelasi Hubungan Dukungan Keluarga Terhadap Keberhasilan Minum Obat ( $\mathrm{n}=48)$

\begin{tabular}{ccc}
\hline Variabel & $\mathrm{R}$ & p-value \\
\hline Dukungan keluarga pasienTB dengan & 0,340 & 0,026
\end{tabular}

Pencegahan Multidrug Resistance

Berdasarkan tabel 4 hasil uji p-value sebesar $0,026<\alpha(0,005)$ hal ini menunjukkan bahwa Ho ditolak atau Ha diterima, menunjukkan bahwa ada hubungan antara dukungan keluarga pasien TB dengan keberhasilan minum obat di
Puskesmas Pajang dan Puskesmas Sangkrah, sedangkan hasil $r$ yaitu 0,340 hal ini menunjukkan bahwa tingkat hubungan antara dukungan keluarga pasien TB dengan keberhasilan minum obat dalam kategori sedang. Hasil analisis bivariat dalam penelitian menunjukkan bahwa ada hubungan 
antara dukungan keluarga dengan kepatuhan minum obat pada penderita

Penelitian ini menunjukkan dukungan keluarga berhubungan dengan keberhasilan minum obat pasien TB. Hasil penelitian Maulidya (2017) menyatakan hal yang sama bahwa ada hubungan yang bermakna antara dukungan keluarga dengan kepatuhan minum obat. Penelitian ini diperkuat oleh penelitian Manalu (2017) yang menyatakan bahwa salah satu faktor yang mempengaruhi keberhasilan pengobatan pada penderita TB adalah dukungan keluarga.

Dukungan keluarga mempunyai peranan penting dalam menambah rasa percaya diri dan memotivasi untuk menghadapi masalah dan meningkatkan kepuasan hidup, keluarga merupakan support sistem utama bagi penderita TB dalam mempertahankan kesehatannya (Hariadi et al., 2019). Penelitian Fadhila \& Gustin (2019) menyatakan bahwa terdapat hubungan yang bermakna antara dukungan keluarga dengan kepatuhan minum obat pada penderita $\mathrm{TB}$, dikarenakan pasien akan merasa senang dan tentram apabila mendapatkan perhatian dan dukungan dari keluarganya.

Dukungan tersebut akan menimbulkan kepercayaan penderita untuk menghadapi atau mengelola penyakitnya dengan lebih baik, serta penderita mau menuruti saran-saran yang diberikan oleh keluarga untuk menunjang pengelolaan penyakitnya. Dengan adanya dukungan keluarga pasien merasa kalau yang merasakan sakit tidak hanya dirinya sendiri, tetapi juga dirasakan oleh keluarganya. Dengan motivasi yang diberikan oleh keluarga, pasien akan merasa semangat dan patuh untuk minum obat. Pada penderita TB yang mendapat dukungan keluarga negatif memiliki peluang untuk tidak patuh dibandingkan responden yang mendapat dukungan keluarga yang positif.

Dukungan keluarga yang positif adalah keluarga berpartisipasi penuh pada pengobatan penderita seperti; pengaturan menu makan dan minum, pola istrahat, perawatan diri terutama kebersihan, pengambilan obat serta 
mampu merujuk penderita bila ada gejala efek samping obat yang berat (Septia et al., 2014). Penelitian yang sama dilakukan oleh Irnawati et al., (2016) bahwa semakin baik dukungan keluarga yang diberikan kepada penderita TB, maka semakin tinggi kepatuhan minum obat, hal ini menunjukkan bahwa dukungan keluarga mempunyai peran penting dalam kepatuhan pasien menjalani pengobatan.

\section{KESIMPULAN DAN SARAN}

Ada hubungan antara dukungan keluarga dengan pencegahan kejadian multidrug resistence pada pasien tuberkulosis di Puskesmas Pajang dan Puskesmas Sangkrah dengan nilai sign $p$ sebesar 0,026. Bentuk dukungan emosional merupakan bentuk dukungan paling tinggi dengan nilai rata-rata sebesar 18,04 .

Hasil penelitian diharapkan dapat meningkatkan dukungan keluarga bagi anggota keluarga yang mengalami penyakit $\mathrm{TB}$, sehingga kasus tuberculosis multidrug resistant bisa dicegah dan diminimalkan serta perlu dilakukan penelitian lebih lanjut dan mendalam mengenai faktor lain yang mempengaruhi kepatuhan minum obat untuk bisa menyeimbangkan faktor dukungan keluarga.

\section{DAFTAR PUSTAKA}

Beauty, A. L. (2016). Hubungan Antara Persepsi dan Dukungan Keluarga dengan Kepatuhan Minum Obat Pasien Baru Tuberkulosis Paru (Studi Kasus di Puskesmas Mejobo Kabupaten Kudus). Skripsi Universitas Negeri Semarang. Retrieved from https://lib.unnes.ac.id/27861/ Fadhila, A., \& Gustin, R. K. (2019). Kepatuhan Penderita Tuberculosis Paru Dalam Menjalani Pengobatan. Jurnal Kesehatan, $\quad 10(1), \quad 47$. https://doi.org/10.35730/jk.v10i 1.384

Hariadi, E., Aryani, F., \& Buston, E. (2019). Relationship of Family Support With the Quality of Life of Tbc. Journal of Nursing 
and Public Health, 7(1), 46-51.

Irnawati, N. M., Siagian, I. E. T., \&

Ottay, R. I. (2016). Pengaruh

Dukungan Keluarga terhadap

Kepatuhan Minum Obat pada

Penderita Tuberkulosis di

Puskesmas Motoboi Kecil Kota

Kotamobagu.

Jurnal

Kedokteran Komunitas Dan

Tropik, 4(1).

Ismah, Z., \& Novita, E. (2017). Studi

Karakteristik

Pasien

Tuberkulosis Di Puskesmas

Seberang Ulu 1 Palembang.

Unnes Journal of Public Health,

6(4),

218-224.

https://doi.org/10.15294/ujph.v6

i4.15219

Janan, M. (2019). Faktor-Faktor Risiko yang Berhubungan dengan Peningkatan Prevalensi Kejadian TB MDR di Kabupaten Brebes Tahun 20112017. Kebijakan Kesehatan Indonesia, 08(02), 64-70.

Kemenkes RI. (2014). Profil Kesehatan Indonesia Tahun 2014. In Profil Kesehatan Provinsi Bali. Retrieved from http://www.depkes.go.id/resour ces/download/pusdatin/profil-

kesehatan-indonesia/Profil-

Kesehatan-Indonesia-2016.pdf

Khasanah, U. (2017). Hubungan

Dukungan Keluarga Dengan

Tingkat Kepatuhan Melakukan

Latihan Jasmani Pada Penderita

Diabetes Melitus Di Puskesmas

Baki Sukoharjo. Skripsi. https://doi.org/10.1002/ejsp.257

0

Kurniawan, N. ', HD, S. R., \& Indriati, G. (2015). FaktorFaktor yang Mempengaruhi Keberhasilan Pengobatan Tuberkulosis Paru. Jurnal Online Mahasiswa (JOM) Bidang Ilmu Keperawatan, 2(1), 729-741. Retrieved from https://jom.unri.ac.id/index.php/ JOMPSIK/article/view/5178/50 58

Laily, D. W., Rombot, D. V, Lampus, B. S., \& Paru, T. (2015). Karakteristik Pasien Tuberkulosis Paru Di Puskesmas Tuminting Manado. Jurnal Kedokteran Komunitas Dan Tropik, 3(1), 1-5.

Manalu, H. S. P. (2017). Faktor- 
Faktor yang Mempengaruhi

Kejadian TB. Paru Dan Upaya Penanggulangannya. Jurnal Ekologi Kesehatan, 9(4), 13401346.

https://doi.org/https://doi.org/10 $.1139 / \mathrm{v} 74-288$

Niven, N. (2012). Psikologi kesehatan: Pengantar untuk perawat \& professional kesehatan lain. Jakarta: EGC.

Sari, R. M. (2014). Hubungan Antara Karakteristik Kontak Dengan Adanya Gejala Tb Pada Kontak Penderita Tb Paru Bta +. Jurnal Berkala Epidemiologi, 2(2), 274-285. Retrieved from ejournal.unair.ac.id/index.php/JB E/article/download/182/52

Septia, A., Rahmalia, S., \& Sabrian, F. (2014). Hubungan Dukungan Keluarga dengan Kepatuhan Minum Obat pada Penderita TB Paru. Jurnal Online Mahasiswa Program Studi Ilmu Keperawatan Universitas Riau, 1(2), 1-10. Retrieved from https://www.neliti.com/publicati ons/185830/hubungandukungan-keluarga-dengan- kepatuhan-minum-obat-padapenderita-tb-paru

Sukmawati, E. (2017). "Efektifitas Penyuluhan Kesehatan Terhadap Pengetahuan Perawatan Pasien Tuberkulosis (TB). " 5(1), 9-20.

Tamamengka, D., \& Kepel, B. (2019). Fungsi Afektif dan Perawatan Keluarga dengan Kepatuhan Pengobatan TB Paru. E-Journal Keperawatan(e-Kp), 7(2), 1-10. Tirtana, B. T. (2011). Faktor-Faktor yang Mempengaruhi Keberhasilan Pengobatan Pada Pasien Tuberkulosis Paru dengan Resistensi Obat Tuberkulosis di Wilayah Jawa Tengah. Skripsi, 1-19.

Tristiana, R. D., Kumalasari, R., \& Makhfudli. (2019). Pengalaman Klien TB Paru yang Menjalani Pengobatan Fase Intensif di Puskesmas Taji Kabupaten Magetan. Jurnal Keperawatan Komunitas, 8(1), 1-10.

WHO. (2015). Global Tuberculosis Report 2015. NASN School 
Nurse (Print), 32(5), 310-316.

https://doi.org/10.1177/1942602

X17698487

WHO. (2016). Global Tuberculosis
Report 2016. European

Respiratory Journal, 44(1), 2363.

https://doi.org/10.1183/0903193

6.00188313 